\title{
IMPACT OF INFORMATION TECHNOLOGY INVESTMENT TO FINANCIAL PERFORMANCE ON BANKING SECTOR
}

\author{
Hendra Gunawan ${ }^{1)}$, Serlyna ${ }^{2)}$ \\ Managerial Accounting Department, Politeknik Negeri Batam \\ Jl. Ahmad Yani, Batam Centre, Batam 29461, Indonesia \\ 1)Email: hendra@polibatam.ac.id \\ ${ }^{2)}$ Email: serlynaaja@gmail.com
}

\begin{abstract}
This study examines the impact of technology on the performance of financial investment in banking companies listed in Indonesia Stock Exchange to prove its influence on the development of the banking company's financial performance. The data used in this research is secondary data uses financial statements that have been audited. Data analysis technique used is simple regression analysis. Results showed that between investments in information technology affect the company's financial performance. The results of this study illustrate that the company's financial performance would be if the investment in information technology in the company are used effectively and efficiently. This research is important for companies and organizations, in order to better the use or utilization of information technology in the enterprise. The company is only limited to the banking companies listed in Indonesia Stock Exchange, then further research is recommended to add criteria and indicator others that have not been addressed in this study, in addition to subsequent authors can also extend the sample population to another company with a different field such as manufacturing companies.
\end{abstract}

Keywords: information technology investments, financial performance 


\section{Introduction}

Companies that decide to invest in addition to hoping to gain profit alone but must also be ready to bear all the possible repercussions of the risks that will occur in the future. Along with the increasing of the Indonesian economy, more competitive company that is able to adapt in order to avoid bankruptcy and ahead of the competition. Companies must maintain and improve performance in an effort to maintain continuity of the company and implement strategic policy of efficient and effective for companies to invest in product and service information technology such as hardware, software, telecommunications training, and consulting. Information technology is a technology related to the processing of data into information and the process of distributing such data or information within the limits of space and time (Indrajit, 2000). According to Farouk \& Dandago (2015), the development of information technology include the development of information technology infrastructure.

Dandago (2015) state that development of information technology including the development of infrastructure information technology to drive the process in delivering superior financial performance, such as employees, hardware, software and automated teller machine (ATM), the technology data storage, and the procedures that operate together to produce information that supports operations and functions of the organization. Developments in information technology not only affect the manufacturing sector, but including the banking sector which provides services to customers in their use of information technology. Forouk and Dandago (2015) revealed the results of a significant relationship between investments in information technology that the total cost of the return on assets (ROA), return on equity (ROE), net profit margin (NPM) and earnings per share (EPS).

Shu and Strassmann (2005) using panel data analysis to investigate the impact of information technology investment as measured by NPM using 12 bank during the 8 -year period. The results of these studies indicate that there is significant correlation between the impacts of information technology investment is measured by NPM. The study found that companies that are able to maintain an optimal level of investment in technology to positively affect earnings and the company's profitability and shareholder value.

This study is a replica of the previous studies that researched by Forouk \& Dandigo (2015) were done in Nigeria. Research conducted by Berger (2003) directing that the use of information technology has increased profit in the service industry, especially the banking industry that use information technology related products such as internet banking, electronic payments, investment security, exchange of information that can provide high quality services to clients with little effort, thereby enhancing financial performance. The application of new technologies in an organization will have an effect on the whole organization, especially in human resources. Factors users is very important to consider in the implementation of new systems and technologies that have a major influence on success whether or not the development or implementation of systems and technology. This, showing information technology can be utilized effectively so that it can become the center of business strategy to gain competitive advantage in the increasingly fierce competition.

Based on the above, the researchers will examine the impact of investment in information technology to the financial performance and whether the technology investment will increase corporate profits, especially in the banking sector listed in Indonesia Stock Exchange in 2012-2014. This study is a replica of Farouk and Dandago research (2015) conducted in Negeria. The focus is to maximize shareholder or investor in investing.

Indonesia and Nigeria is a developing country in the use of information technology has not been on par with developed countries, the investors to invest in information technology to companies in order not to miss on the use of technology globally. This investment aims to improve the financial performance of the company, so the company can continue to grow sustainably.

\section{Review Literature}

Information technology is a technology related to the processing of data into information and the process of distributing such data or information within the limits of space and time (Indrajit, 2000). According to Farouk \& Dandago (2015), the development of information technology include the development of information technology infrastructure to drive the process in delivering superior financial performance, such as employees, hardware, software and automated teller machine, technology data storage and the procedures that operate together to produce information to support the operation and functioning of the organization. Developments in information technology not only affect the manufacturing sector, but including the banking sector which provides services to customers in their use of information technology.

The theory of investment management is the process of managing money (Fabozzi, 1995). Investment is essentially the placement of the funds with the hope of gain in the future next (Halim, 2005). According to 
SFAS No. 13 accounting standards as of October 1, 2004, the investment is an asset which is used by the company to grow the wealth through the distribution of investment returns (such as interest, royalty dividend and rents), to the appreciation of the value of investments, and provide other benefits to companies that invest like the benefits obtained through trade relations.

Some understanding of the investment, namely: First, the current investment is an investment that can be cleared and is intended to be held for one year or less. Second, long-term investment is an investment other than current investment. The third property investment is an investment in land or buildings that are not used or operated by the investing company or other companies in the same group as the investing company. One of the components of financial statements that can be used by investors is the income statement. SFAS No. 25 states that the income statement is the main report to report performance on a period. Information on the performance of companies provide information about cash and assets equated to cash in the future. Profit in the accounting theory usually shows the FASB concept referred to a comprehensive income. Comprehensive profit is defined as the increase in net assets other than those arising from transactions with owners (Suwardjono, 2011)

Profit is defined and interpreted as a measure of efficiency in the use of resources in the form of return of assets. Efficiency is the ability to achieve the return on assets with the lowest resource (Suwardjono, 2011). Profit is divided into two: first, the economic concept of profit is profit from the glass eyes of investors because of the need to assess investment in stocks that are subjective depend on the characteristics of the investor. Second, the accounting profit is profit from engineering glasses accounting or business units for the purpose of presenting information in an objective and reliable (Suwardjono, 2011).

Based on some of the above definitions of profit theory is the theory of general profit is the difference of income over expenses in a given time period that restored capital. According to Pyle \& Kermit (1981), the accounting profit is the difference between the buyer and the cost of goods shipped component services of each operation or other expenses.

Theory profitability is the image of the company's ability to generate profits by using the entire capital of the company (Shapiro, 1991). The company's profitability may influence the policy of investors on the investment made. The company's ability to generate profits will attract investors to raise funds to expand its business. The company's profitability can be used as an evaluation of the effectiveness of the entity business management. According Husnan, (2001), profitability is the ability of a company to generate profit (profit) on the level of sales, assets, and a specific share capital. According to Michelle \& Megawati, (2005) the profitability of a company's ability to generate profits (profit) which will be the basis of dividend distribution companies.

\section{Research Methodology}

This study uses some research variables, namely: Investment Technology (BT), Return on Assets (ROA), return of equity (ROE), Net Profit Margin (NPM), and Earnings per Share (EPS). The object of this research is the company's annual financial statements published by the company services this study uses several variables that are listed on the Stock Exchange. This data was obtained from the official website of the Stock Exchange (www.idx.co.id). Tests in this study using SPSS 22. The population in this study are all services company from 2012 to 2014 . The sample used as the object of this research is purposive sampling.

TABLE 1

DETERMINATION OF SAMPLES

\begin{tabular}{ccc}
\hline No & Description & $\begin{array}{c}\text { number of } \\
\text { companies }\end{array}$ \\
\hline 1 & There is a banking company in Indonesia Stock Exchange 2012 & 75 \\
2 & Companies that do not meet criteria for the year 2012 & 19 \\
3 & Total sample during the years 2013 & 56 \\
\hline
\end{tabular}

The criteria for the determination of the samples in this study are: first sample is selected banking companies listed in Indonesia Stock Exchange in 2012-2014. Both have complete data associated with variables research. The independent variable is the total cost of information technology expenditures incurred. The dependent variable in this study are: ROA, ROE, NPM, and EPS.

\section{Results and Discussion}

Based on Table 2, it can be seen that the number of observations in the study (N) is 56. Variable technology investment has a minimum value of 15.525 on the company BBAG and BBMA and a maximum value of 28.289. Overall gained an average of 23.027 and a standard deviation of 2.883 variable. ROA has a minimum value of 0.10 at companies BBBA maximum values of 5.57 at companies BNLI. 
TABLE 2

DESCRIPTIVE STATISTIC

\begin{tabular}{|c|c|c|c|c|c|c|c|c|}
\hline & \multirow[b]{2}{*}{$\mathrm{N}$} & \multirow[b]{2}{*}{ Range } & \multirow{2}{*}{\multicolumn{2}{|c|}{ Minimum Maximum }} & \multirow[b]{2}{*}{ Mean } & \multicolumn{3}{|c|}{ Std. } \\
\hline & & & & & & & Deviation & Variance \\
\hline & Statistik & Statistik & Statistik & Statistik & Statistik & Error & Statistik & Statistik \\
\hline BT & 56 & 12,764 & 15,525 & 28,289 & 23,0275 &, 385389 & 2,883986 & 8,317 \\
\hline ROA & 56 & 5,560 & .010 & 5,570 & 2,80116 & 200676 & 1,501720 & 2,255 \\
\hline ROE & 56 & 6,690 &, 000 & 6,690 & 2,78400 & ,286233 & 2,141975 & 4,588 \\
\hline NPM & 56 & 9,026 &, 000 & 9,026 & 3,58313 & ,391264 & 2,927949 & 8,573 \\
\hline EPS & 56 & 6,885 &, 000 & 6,885 & 2,73100 &, 265728 & 1,988527 & 3,954 \\
\hline Valid $N$ & & & & & & & & \\
\hline (listwise) & 50 & & & & & & & \\
\hline
\end{tabular}

TABLE 3

NORMALITY TEST

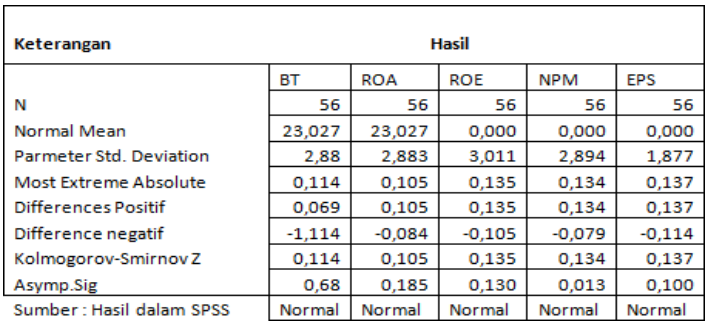

Overall average of 2,801 and a standard deviation of 1.501. ROE has a minimum value of $\$ 0.00$ on the company BNI and BBS. While the maximum value obtained 5.570 overall average of 2,874 and a standard deviation of 2.417. Variable NPM has a minimum value of 0.00 at companies BBNI, BBNP, and BBND while the maximum value of 9,670 Overall average of 3.83 and a standard deviation of 2.97. Variable EPS has a minimum value of 0:00 at companies BTPN and BSIM while the maximum value of 6,886 . Overall average of 2.730 with a standard deviation of 1.998 .

TABLE 4

\begin{tabular}{|c|c|c|c|c|}
\hline \multicolumn{5}{|c|}{ RESULT OF HYPOTHESIS TEST } \\
\hline & \multicolumn{2}{|c|}{ SE } & Beta & Sig \\
\hline Model 1 & & & & \\
\hline Constant & $-0,359$ & 1,586 & & $-0,2260,822^{* *}$ \\
\hline ROA & 0,137 & 0,068 & 0,264 & $2,0070,05^{* *}$ \\
\hline R Square & 0,069 & & & \\
\hline \multicolumn{5}{|l|}{ Model 2} \\
\hline Constant & $-3,144$ & 2,2 & & $-1,4290,159^{* *}$ \\
\hline ROE & 0,257 & 0,095 & 0,347 & $2,7150,009^{* *}$ \\
\hline R Square & 0,12 & & & \\
\hline \multicolumn{5}{|l|}{ Model 3} \\
\hline Constant & 0,049 & 3,168 & & $0,0150,988^{* *}$ \\
\hline NPM & 0,153 & 0,137 & & $1,1240,266^{* *}$ \\
\hline R Square & 0,023 & & & \\
\hline \multicolumn{5}{|l|}{ Model 4} \\
\hline Constant & $-1,932$ & 2,081 & & $-0,9280,357^{* *}$ \\
\hline NPM & 0,202 & 0,09 & 0,294 & $2,2580,028^{* *}$ \\
\hline R Square & 0,086 & & & \\
\hline
\end{tabular}

From Table 3, it can be seen that the value of the variable investment technology $\mathrm{KS}$ for information (BT) is 0.114 with $\mathrm{p}=0.68$, ROA has KS $0.105, \mathrm{p}=$ 0.185 , ROE has KS $0.135, \mathrm{p}=0.130$, variable NPM has KS $0.134, p=0.013$ and variable KS EPS has 0,137 with $\mathrm{p}=0.100$. The results of the KolmogorovSmirnov test statistic is above 0.05 , thus it can be concluded that all variables have normal distribution. Testing the influence of the independent variable on the dependent variable can be seen from the Table 4 . Based on Table 4 , it can be concluded by simple linear regression equation as follows:

$$
\mathrm{Y}=-0,359+0,137(\mathrm{BT})
$$

ROA test results obtained t-calculate equal to 2.007 the positive significance of 0.05 . The significant value equivalent to 0.05 so that it can be concluded that the hypothesis 1 is supported, which means there is positive between investments in information technology to financial performance as measured by ROA. The coefficient of determination is equal to 0.069 . Then it can be said that investment in information technology affects $6.9 \%$ of the ROA. The remaining $93.1 \%$ is influenced by other variables not studied.

Based on Table 4 above, it can be concluded by simple linear regression equation as follows:

$$
\mathrm{Y}=-3,144+0,257(\mathrm{BT})
$$

The test results obtained $\mathrm{t}$ count ROE amounted to 2,715 with the positive significance of 0.009 . The significant value equivalent to 0.05 so that it can be concluded that the second hypothesis is supported, which means there is positive between investments in information technology to financial performance as measured by ROE. The coefficient of determination value is equal to 0.120 . It can be concluded that the investment in information technology affects $12 \%$ of the ROE. The remaining $98.8 \%$ is influenced by other variables not studied.

Based on Table 4, we can conclude simple linear regression equation as follows:

$$
\mathrm{Y}=0,049+0,153(\mathrm{BT})
$$

NPM test results obtained $t$ count equal to 1,124 with significant amounted to 0,266 . The significant values above 0.05 so it can be concluded that the third hypothesis is not supported, which means there are no significant positive effect between investments in information technology to financial performance as 
measured by NPM. The coefficient of determination value is equal to 0,023 . It can be concluded that the investment in information technology affects $2.3 \%$ of the NPM. The remaining $97.7 \%$ is influenced by other variables not studied.

Based on Table 4 above, we can conclude simple linear regression equation as Follows:

$$
\mathrm{Y}=-1,932+0,202(\mathrm{BT})
$$

EPS test results obtained t count equal to 2,258 with positive significance of 0.028 . The significant value equivalent to 0.05 so that it can be concluded that the hypothesis 4 is supported, which means there is positive between investments in information technology to financial performance as measured by EPS. The coefficient of determination value is equal to 0.86. It can be concluded that the investment in information technology affects $8.6 \%$ of the NPM. The remaining $99.4 \%$ influenced by other variables not studied.

\section{Conclusions}

This study contains a model to test the effect of the impact of information technology investments to financial performance. Based on the results with SPSS regression testing, it can be concluded that: first, the impact of investment in information technology has positive influence on ROA. Second, the impact of information technology investment positive effect on ROE. Third, the impact of information technology investment effects adversely NPM. Fourth, the impact of information technology investment positive effect on EPS.

\section{References}

Berger. (2003). The Effect of Technological Economic Progress: Evidence from the Banking Industry. Journal of Money, Credit Bank.

Dudley, \& Lassere. (1990). Impact of Information Technology in business and the Organization Efforts to Realize the Benefits of Positive. Journal of Economics and Management.

Dwivedi. (2002). Managerial Economics. New Delhi: Vikas Publishing House Ltd.

Ekata. (2012). The IT Productivity paradox: Evidence from the Nigerian Banking Industry. Electronic Journal on Information Systems in Developing Countries, 1-22.
Fabozzi, F. J. (1995). Investment Management.

Jakarta.Salemba Four.

Fahmi, I. (2011). Financial performance. Yogyakarta: Alfabeta.

Forouk, \& Dandigo. (2015). Impact of Investment in Information Technology on Financial Performance of Nigerian Banks: Is there a productivity Paradox? Journal of Internet Banking and Commerce.

Franke, R. (1987). Cultural Roots of Economic Implication. Management Journal, 165-173.

Ghozali, I. (2012). Applications Multivariate analysis using SPSS. Semarang: Diponegoro University Publishers Agency.

Hanafi, M. M., \& Halim, A. (2003). The analysis of Financial Statements. Yogyakarta: Liberty.

Helfert, E. A. (2000). Financial Analysis Techniques: A Practical Guide for Managing and Measuring Corporate Performance. Jakarta: The eighth edition, Erland.

Halim, (2005). Manajemen Investasi. Yogyakarta: Erland.

Haris, (2009). Measurement of financial performance using economic value added. International Journal of Business Management.

Husnan, S. (2001). Basic-dasar Teori Portfolio and Securities Analysis. Yogyakarta.

Indrajit. (2000). Management Information Systems and Information Technology. Elex Media komputando.

Kwon, \& Stoneman. (1995). The effect on the financial performance of technology investments. Journal of Economic Management.

Michelle, and Megawati. (2005). Return on investment can be predicted through profitability, liquidity, Laverage. Economic Journals.

Oliner, S. \& Sichel, D. (2000). Information Technology and Productivity. Atlanta Economic Review, 15-44. 
Prastowo, D. (2008). Financial Statement Analysis; Second Edition of the School of Management YKPN.

Putu, N. 1. (2010). Fundamentals of Financial Management. Denpasar: Udayana University Press.

Pyle, and Kermit. (1981). Fundamental Accounting Principle: McGraw-Hill.

Salehi et al. (2014). The Relationship between Intellectual Capital with Economic Value Added and Financial Performance. Iranian Journal of Management Studies, 1-5.

Shapiro. (1991). profitability Ratio. Semarang: Alfabeta.

Shu, and Strassmann. (2005). Does Information Technology Provide Banks with Profit? , Information and Management, 479-501.
Simon, J., \& Wardrop, S. (2002). Australia Use of Information Technology and Its contribution To Growth. Economic Research.

Sircar, K. (2000). A framework for assessing the Relationship between Investment Information Technology. Journal of Management Information System.

Suwardjono (2011). Accounting Theory. Yogyakarta: BPFE

Tjiptono, and Hendri. (2001). Effect of Earnings per Share of Stock Price Changes.

Single, A. W. (2001). Understanding the Concept of Economic value Added (EVA) and Value-based Management (VBM).

Utomo. (1999). Added economic value as a measure of performance success of the Company's management. Journal of Accounting and Finance Vol.1.

Xiang, \& Kim. (2009). Technology Forecasting \& Social. Account of Business Admiration. 